\title{
RESPONSE OF T. AMAN AND BORO RICE TO RESIDUE RETENTION UNDER STRIP TILLAGE
}

\author{
M. M. Hossain ${ }^{1 *}$, M. Begum ${ }^{1}$, M.M. Rahman' ${ }^{1}$ and A. Hashem ${ }^{2}$ \\ ${ }^{1}$ Department of Agronomy, Bangladesh Agricultural University \\ ${ }^{2}$ Department of Agriculture and Food, Western Australia \\ *Corresponding author and E-mail address: mmhshakil@yahoo.com
}

Key words: Unpuddled transplanting, conventional tillage, strip tillage, residue retention

\begin{abstract}
An on-farm research was conducted at Gouripur upazila under Mymensingh district of Bangladesh during aman and boro season in 2013-14 to evaluate the performance of unpuddled rice cultivation. The rice var. Hybrid Krishan2 in aman and BRRI dhan28 in boro season were transplanted by two tillage practices viz., conventional tillage (CT) and strip tillage (ST) and two levels of crop residue i.e, no residue $\left(\mathrm{R}_{0}\right)$ and $50 \%$ residue $\left(\mathrm{R}_{50}\right)$. The experiment was designed in a randomized complete block design with four replications. ST yielded higher grains in aman season $\left(5.67 \mathrm{t} \mathrm{ha}^{-1}\right)$ and also in boro season $\left(4.70 \mathrm{t} \mathrm{ha}^{-1}\right)$ which were 9 and 13\% higher compared to CT. Higher grain yield in ST leading to 26\% higher BCR in aman and 23\% higher in boro compared to CT. Retention of 50\% residue increased by $5 \%$ yield in aman and by $4 \%$ yield in boro compared to no residue which contributed to $9 \%$ higher BCR in both aman and boro. ST combine with 50\% residue retention yielded the highest grain yield in both of aman $\left(5.97 \mathrm{t} \mathrm{ha}^{-1}\right)$ and boro season $\left(4.81 \mathrm{t} \mathrm{ha}^{-1}\right)$ which attributed to obtain the highest BCR in aman (3.08) and boro (2.78).
\end{abstract}

\section{Introduction}

Most of the farmers in the Asian continent cultivate rice (Oryza sativa L.) seedlings by transplanting in puddled soil for easy crop establishment (Singh et al., 2014). Lands are prepared by single or two passes in dry condition followed by exposure to sun for a couple of days. Then after inundation, final land is prepared by ploughing, cross ploughing and laddering in standing water. However, this traditional puddling method is labour, fuel, time and capital consuming (Islam et al., 2014). Nowadays most of tillage operations for puddling soil in Bangladesh are done by power tiller (Haque et al. 2008; Miah et al., 2002). Puddling is detrimental to soil physical conditions (Hobbs and Morris, 1996) through destroying soil aggregates, breaking capillary pores, and dispersing the soils (Gupta et al., 2003). Cloddy soil structure with less soil moisture and inadequate seed-soil contact resulted from the puddling (Sharma et al., 1995) makes land preparation difficult for the following winter crops (Islam et al. 2014). Puddled rice transplanting consumes about 20-40\% of total water required for raising crop (Singh et al., 2014) and it also promotes the formation of hard pan (Bhuiyan et al., 1995), reduces soil organic carbon at double rate, and decreases soil fertility (Grace, 2003), has losses of irrigation water (Sayre and Hobbs, 2003), and damages the ecological environment (Grace, 2003). Adoption of minimum tillage may be a very good alternative to puddled transplanting as it is using widely for many crops around the world (Singh et al., 2014). This technology has potentials to allow saving in labour, energy, water and time during rice establishment (Piggin et al., 2002). Compared to conventional tillage, 25-26\% water could be saved by strip tillage under unpuddled system (Islam et al., 2012). Crop residues of cultivated crops are a significant factor for crop production through their effects on soil physical, chemical and biological functions as well as water and soil quality and increase crop yield (Kumar and Goh, 2000). Residue practice maintains soil micro-organisms and microbial activity which can also lead to weed suppression by the biological agents leading to increase crop yield (Kennedy, 1999). Considerable research work has been done on puddle transplanting, but there is alimited information on unpuddled rice transplanting under Bangladesh 
Hossain et al.

condition. Therefore, the present study was conducted to examine the performance of rice to unpuddled transplanting system with the retention of crop residues.

\section{Materials and Methods}

The experiment was conducted at farmer's field of Durbacahra, Guipure, Mymensingh, Bangladesh (the latitude of $24.75^{\circ} \mathrm{N}$ and the longitude of $90.50^{\circ} \mathrm{E}$ ) during aman (July-Mid November) and boro (Mid November-June) season in 2013-14. This experimental area belongs to the Old Brahmaputra Floodplain which is characterized by dark grey non calcareous alluvium soils and these soils are mostly sandy loam under Sonatala series (Brammer, 1996). Climatic (rainfall and thermal condition) data were collected from the nearest weather station and are presented in Figure 1.

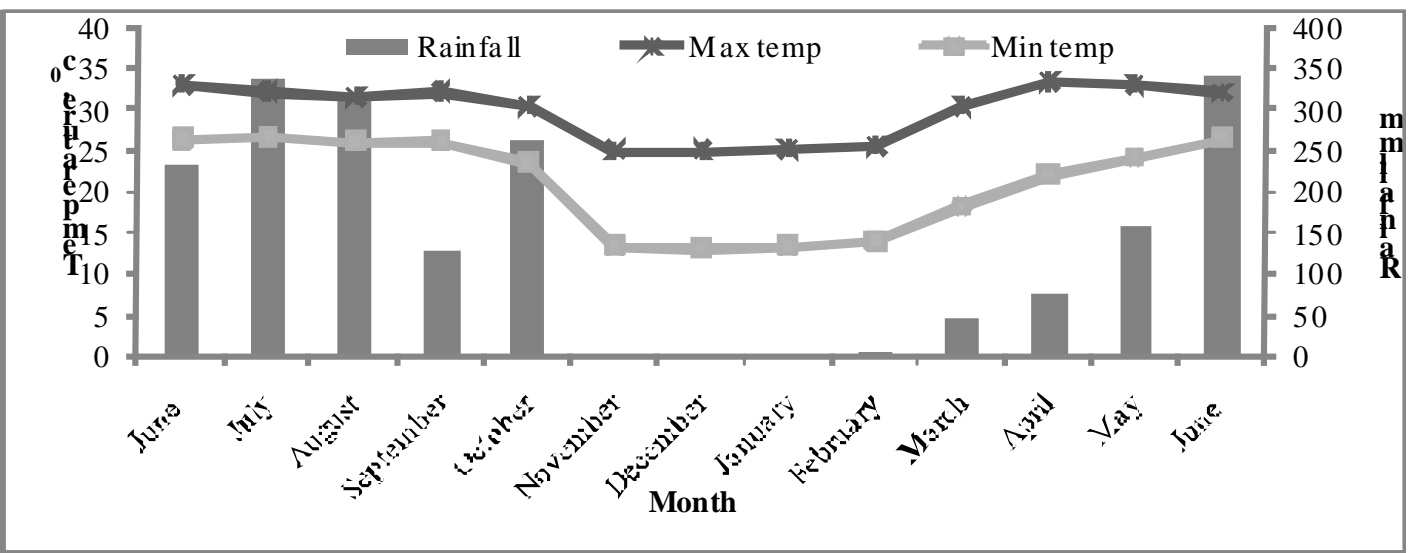

Fig.1. Monthly temperature and rainfall distribution pattern in Gouripur during the cropping season of 2013-14

[Source: Department of Irrigation and Water Management, Faculty of Agricultural Engineering and Technology, Bangladesh Agricultural University, Mymensingh]

The treatments were: (i) ipuddled condition conventional tillage (CT) and (ii) unpuddled condition strip tillage (ST) and two levels of crop residue viz., no residue $\left(\mathrm{R}_{0}\right)$ and $50 \%$ residue $\left(\mathrm{R}_{50}\right)$. The treatments were laid out in randomized complete block design with four replications using unit plots of $9 \mathrm{~m} \times 5 \mathrm{~m}$. In tillage practice, CT consisted of two passes primary tillage by two wheeler tractor $(2$ WT) and exposed to sun for two days followed by inundating whole plot and puddling by 2WT with two passes to complete land preparation. ST was done by Versatile Strip Tillage Planter (VSTP) in single pass operation before inundating the field. Three days before ST, pre-plant Glyphosate (Roundup) was applied @ $75 \mathrm{ml} / 10 \mathrm{~L}$ water. After ST, the land was inundated with 3-5 cm standing water one day before transplanting operation for making the land soft enough to transplant seedlings (Islam et al., 2014). Twenty-five days old seedlings of rice var. Hybrid Krishan2 for aman season, and 40 days old seedlings of BRRI dhan 28 for boro season were transplanted. Fertilizers were applied according to the recommendation of BRRI (2014). A spacing of $25 \mathrm{~cm} \times 15 \mathrm{~cm}$ was maintained for both CT and ST with 2 or 3 seedlings hill ${ }^{-1}$. The crops were harvested at maturity from $3 \mathrm{~m} \times 3 \mathrm{~m}$ each and then data were recorded. Grain yields were adjusted to $14 \%$ moisture content. Data were subjected to ANOVA using MSTAT-C and means separated by Duncan's Multiple Range Test.

\section{Results and discussions}

\section{Effect of tillage practice on yield contributing characters and yield of rice}


Yield contributing characters of rice were significantly affected due to different tillage practice except the plant height, panicle length, and thousand grain weight (Table 1). The highest numbers of effective tillesr $\mathrm{m}^{-2}$ and numbers of fertile grains panicle ${ }^{-1}$, and the lowest numbers of non-effective tillesr $\mathrm{m}^{-2}$ and numbers of sterile grains panicle ${ }^{-1}$ were recorded from the ST compared to CT which attributed to higher yield ( $9 \%$ higher in aman and 13\% higher in boro) for ST (Table 1). On the other hand, unpuddled rice transplanting by following ST produced higher BCR (around 25\% in aman and $23 \%$ higher in boro compared to CT (Table 1).

Table 1. Effect of tillage practice on yield contributing characters and yield of rice

\begin{tabular}{|c|c|c|c|c|c|c|c|c|c|}
\hline $\begin{array}{l}\text { Tillage } \\
\text { practice }\end{array}$ & $\begin{array}{l}\text { Plant } \\
\text { height } \\
(\mathrm{cm})\end{array}$ & $\begin{array}{c}\text { Effective } \\
\text { tillers } \mathrm{m}^{-2} \\
\quad(\mathrm{no})\end{array}$ & $\begin{array}{c}\text { Non } \\
\text { effective } \\
\text { tillers } \mathrm{m}^{-2} \\
\quad \text { (no) }\end{array}$ & $\begin{array}{c}\text { Panicle } \\
\text { length } \\
(\mathrm{cm})\end{array}$ & $\begin{array}{c}\text { Fertile } \\
\text { grains } \\
\text { panicle }^{-1} \\
\text { (no) }\end{array}$ & $\begin{array}{c}\text { Sterile } \\
\text { grains } \\
\text { panicle }^{-1} \\
\text { (no) }\end{array}$ & $\begin{array}{l}\text { 1000- } \\
\text { grain } \\
\text { weight } \\
(\mathrm{gm})\end{array}$ & $\begin{array}{c}\text { Grain } \\
\text { yield } \\
\left(\mathrm{t} \mathrm{ha}^{-1}\right)\end{array}$ & $\begin{array}{c}\text { Benefit } \\
\text { Cost } \\
\text { Ratio }\end{array}$ \\
\hline \multicolumn{10}{|c|}{ Aman season } \\
\hline CT & 110.42 & $209 b$ & $71 \mathrm{a}$ & 24 & $139 b$ & $47 \mathrm{a}$ & 30 & $5.18 \mathrm{a}$ & $1.76 b$ \\
\hline ST & 109.99 & $261 \mathrm{a}$ & $44 b$ & 25 & $157 \mathrm{a}$ & $29 b$ & 31 & $5.67 \mathrm{~b}$ & $2.21 \mathrm{a}$ \\
\hline $\operatorname{LSD}_{(0.05)}$ & NS & 1.37 & 12.41 & NS & 5.48 & 2.55 & 0.41 & 0.22 & 0.13 \\
\hline $\mathrm{CV}(\%)$ & 2.74 & 12.67 & 11.71 & 2.40 & 3.47 & 2.27 & 1.32 & 0.34 & 4.72 \\
\hline \multicolumn{10}{|c|}{ Boro season } \\
\hline $\mathrm{CT}$ & 107.32 & $361 b$ & $77 \mathrm{a}$ & 23.92 & $111 \mathrm{~b}$ & $35 a$ & 21.91 & $4.17 \mathrm{~b}$ & $2.16 \mathrm{~b}$ \\
\hline ST & 105.60 & $382 a$ & $47 b$ & 24.39 & $132 \mathrm{a}$ & $16 \mathrm{~b}$ & 23.00 & $4.70 \mathrm{a}$ & $2.67 \mathrm{a}$ \\
\hline $\operatorname{LSD}_{(0.05)}$ & NS & 4.60 & 3.00 & NS & 8.29 & 2.90 & NS & 0.09 & 0.03 \\
\hline $\mathrm{CV}(\%)$ & 4.60 & 1.20 & 5.68 & 3.84 & 5.14 & 8.88 & 6.83 & 2.10 & 1.24 \\
\hline
\end{tabular}

In a column, figure with similar letter do not differ significantly whereas dissimilar letter differ significantly.

$\mathrm{CT}=$ Conventional tillage, $\mathrm{ST}=$ Strip tillage,

\section{Effect of residue retention on yield contributing characters and yield of rice}

Retention of $50 \%$ residue improved the numbers of effective tiller $\mathrm{m}^{-2}$ and the numbers of fertile grain panicle $^{-1}$ while declined the numbers of non-effective tiller $\mathrm{m}^{-2}$ and the numbers of sterile grain panicle $^{-1}$, compared to no residue in both aman and boro season (Table 2).

Higher residue level yielded around 5\% higher grains of Hybrid Krishan2 and 4\% higher grains of BRRI dhan28 rice which attributed to earned 9\% higher BCR in both aman and boro season (Table 2).

Table 2. Effect residue level on yield contributing characters and yield of rice

\begin{tabular}{|c|c|c|c|c|c|c|c|c|c|}
\hline $\begin{array}{c}\text { Residue } \\
\text { level }\end{array}$ & $\begin{array}{l}\text { Plant } \\
\text { height } \\
(\mathrm{cm})\end{array}$ & $\begin{array}{l}\text { Effective } \\
\text { tillers } \mathrm{m}^{-2} \\
\quad \text { (no) }\end{array}$ & $\begin{array}{c}\text { Non } \\
\text { effective } \\
\text { tillers m-2 } \\
\text { (no) }\end{array}$ & $\begin{array}{c}\text { Panicle } \\
\text { length } \\
(\mathrm{cm})\end{array}$ & $\begin{array}{c}\text { Fertile } \\
\text { grains } \\
\text { panicle }^{-1} \\
\text { (no) }\end{array}$ & $\begin{array}{c}\text { Sterile } \\
\text { grains } \\
\text { panicle }{ }^{-1} \\
\text { (no) }\end{array}$ & $\begin{array}{c}1000 \\
\text { grain } \\
\text { weight } \\
(\mathrm{gm})\end{array}$ & $\begin{array}{l}\text { Grain } \\
\text { yield } \\
\left(\mathrm{t} \mathrm{ha}^{-1}\right)\end{array}$ & $\begin{array}{c}\text { Benefit } \\
\text { Cost } \\
\text { Ratio }\end{array}$ \\
\hline \multicolumn{10}{|c|}{ Aman season } \\
\hline $\mathrm{R}_{0}$ & 110.60 & $236 b$ & 53 & 24.59 & $148 b$ & $33 a$ & $31.70 \mathrm{~b}$ & $5.50 \mathrm{~b}$ & $2.61 b$ \\
\hline $\mathrm{R}_{50}$ & 109.52 & $265 \mathrm{a}$ & 40 & 24.51 & $157 \mathrm{a}$ & $29 b$ & $32.06 \mathrm{a}$ & $5.76 \mathrm{a}$ & $2.86 \mathrm{a}$ \\
\hline $\operatorname{LSD}_{(0.05)}$ & NS & 0.79 & NS & 0.31 & 3.16 & 1.47 & 0.23 & 0.13 & 0.75 \\
\hline $\mathrm{CV}(\%)$ & 2.74 & 12.67 & 11.71 & 2.40 & 3.47 & 2.27 & 1.32 & 0.34 & 4.72 \\
\hline
\end{tabular}


Hossain et al.

\begin{tabular}{|c|c|c|c|c|c|c|c|c|c|}
\hline \multicolumn{10}{|c|}{ Boro season } \\
\hline $\mathrm{R}_{0}$ & 104.90 & $373 b$ & $58 b$ & 24.39 & $100 \mathrm{a}$ & $22 \mathrm{a}$ & 22.71 & $4.52 b$ & $2.48 \mathrm{~b}$ \\
\hline $\mathrm{R}_{50}$ & 106.37 & $385 a$ & $46 a$ & 24.25 & $121 \mathrm{e}$ & $17 b$ & 22.93 & $4.70 \mathrm{a}$ & $2.69 \mathrm{a}$ \\
\hline $\operatorname{LSD}_{(0.05)}$ & NS & 2.65 & 1.73 & NS & 4.78 & 1.67 & NS & 0.05 & 0.018 \\
\hline CV $(\%)$ & 4.60 & 1.20 & 5.68 & 3.84 & 5.14 & 8.88 & 6.83 & 2.10 & 1.24 \\
\hline
\end{tabular}

In a column, figure with similar letter do not differ significantly whereas dissimilar letter differ significantly.

$\mathrm{R}_{0}=$ No residue, $\mathrm{R}_{50}=50 \%$ residue,

Combination effect of tillage practice and residue level on yield contributing characters and yield of rice

Combination between tillage practice and residue level exerted significant effect on all the plant characters except plant height, panicle length and weight of thousand grain in both aman and boro season (Table 3). ST retained 50\% residue produced the highest number of effective tillers $\mathrm{m}^{-2}$, and number of fertile grains panicle ${ }^{-1}$, and the lowest numbers of non-effective tiller $\mathrm{m}^{-2}$ and number of sterile grains panicle ${ }^{-1}$ for both in aman and boro season. CT or ST with residue yielded the higher values of these parameters compared to no residues. ST with residue yielded the highest grain yield leading to the highest BCR while CT without residue yielded the lowest grain yield consequently the lowest BCR both in aman and boro season.

Table 3. Combination effect of tillage practice and residue level on yield contributing characters and yield of rice

\begin{tabular}{|c|c|c|c|c|c|c|c|c|c|c|}
\hline $\begin{array}{c}\text { Tillage } \\
\text { practice }\end{array}$ & $\begin{array}{c}\text { Residue } \\
\text { level }\end{array}$ & $\begin{array}{l}\text { Plant } \\
\text { height } \\
(\mathrm{cm})\end{array}$ & $\begin{array}{c}\text { Effective } \\
\text { tillers } \\
\mathrm{m}^{-2}(\mathrm{no})\end{array}$ & $\begin{array}{c}\text { Non } \\
\text { effective } \\
\text { tillers } \\
\mathrm{m}^{-2}(\text { no })\end{array}$ & $\begin{array}{c}\text { Panicle } \\
\text { length } \\
(\mathrm{cm})\end{array}$ & $\begin{array}{c}\text { Fertile } \\
\text { grains } \\
\text { panicle } \\
{ }_{1}(\text { no }) \\
\end{array}$ & $\begin{array}{c}\text { Sterile } \\
\text { grains } \\
\text { panicle }^{-1} \\
\text { (no) }\end{array}$ & $\begin{array}{c}1000 \\
\text { grain } \\
\text { weight } \\
(\mathrm{gm})\end{array}$ & $\begin{array}{c}\text { Grain } \\
\text { yield } \\
\left(\mathrm{t} \mathrm{ha}^{-1}\right)\end{array}$ & $\begin{array}{c}\text { Benefit } \\
\text { Cost } \\
\text { Ratio }\end{array}$ \\
\hline \multicolumn{11}{|c|}{ Aman season } \\
\hline \multirow{2}{*}{$\mathrm{CT}$} & $\mathrm{R}_{0}$ & 109.30 & $207 \mathrm{~cd}$ & $78 \mathrm{~d}$ & 24.20 & $119 d$ & $53 a$ & 28.50 & $5.17 \mathrm{~cd}$ & $1.63 \mathrm{c}$ \\
\hline & $\mathrm{R}_{50}$ & 111.55 & $211 \mathrm{c}$ & $63 c$ & 24.60 & $140 \mathrm{c}$ & $43 b$ & 31.28 & $5.20 \mathrm{c}$ & $1.76 \mathrm{c}$ \\
\hline \multirow{2}{*}{ ST } & $\mathrm{R}_{0}$ & 110.87 & $241 b$ & $49 b$ & 24.67 & $154 \mathrm{~b}$ & $29 c$ & 30.84 & $5.57 \mathrm{~b}$ & $2.76 b$ \\
\hline & $\mathrm{R}_{50}$ & 109.12 & $280 \mathrm{a}$ & $35 \mathrm{a}$ & 24.50 & $160 \mathrm{a}$ & $26 \mathrm{c}$ & 31.37 & $5.97 \mathrm{a}$ & $3.08 \mathrm{a}$ \\
\hline \multirow{2}{*}{\multicolumn{2}{|c|}{$\begin{array}{l}\operatorname{LSD}_{(0.05)} \\
\mathrm{CV}(\%)\end{array}$}} & NS & 1.95 & 10.88 & NS & 5.76 & 3.60 & NS & 0.32 & 0.18 \\
\hline & & 2.74 & 12.67 & 11.71 & 2.40 & 3.47 & 2.27 & 1.32 & 0.34 & 4.72 \\
\hline \multicolumn{11}{|c|}{ Boro season } \\
\hline \multirow{2}{*}{$\mathrm{CT}$} & $\mathrm{R}_{0}$ & 108.35 & 359 & $84 a$ & 24.35 & $100 \mathrm{c}$ & $41 \mathrm{a}$ & 21.60 & $4.12 \mathrm{~d}$ & $2.08 \mathrm{~d}$ \\
\hline & $\mathrm{R}_{50}$ & 106.30 & 363 & $70 b$ & 24.50 & $121 \mathrm{~b}$ & $30 \mathrm{~b}$ & 22.23 & $4.24 c$ & $2.24 \mathrm{c}$ \\
\hline \multirow{2}{*}{ ST } & $\mathrm{R}_{0}$ & 104.21 & 376 & $53 c$ & 24.40 & $129 \mathrm{ab}$ & $18 \mathrm{c}$ & 22.93 & $4.60 \mathrm{~b}$ & $2.56 \mathrm{~b}$ \\
\hline & $\mathrm{R}_{50}$ & 106.38 & 388 & $41 \mathrm{~d}$ & 24.20 & $139 a$ & $15 \mathrm{c}$ & 23.07 & $4.81 \mathrm{a}$ & $2.78 \mathrm{a}$ \\
\hline \multirow{2}{*}{\multicolumn{2}{|c|}{$\begin{array}{l}\operatorname{LSD}_{(0.05)} \\
\mathrm{CV}(\%)\end{array}$}} & NS & 6.50 & 4.25 & NS & 11.72 & 4.11 & NS & 0.13 & 0.045 \\
\hline & & 4.60 & 1.20 & 5.68 & 3.84 & 5.14 & 8.88 & 6.83 & 2.10 & 1.24 \\
\hline
\end{tabular}

In a column, figure with similar letter do not differ significantly whereas dissimilar letter differs significantly.

$\mathrm{CT}=$ Conventional tillage, $\mathrm{ST}=$ Strip tillage, $\mathrm{R}_{0}=$ No residue, $\mathrm{R}_{50}=50 \%$ residue

The higher rice yields in ST obtained in this study are in the conformity with results of Mahajan et al. (2002) and Heatherly et al. (1994)

Residue converts to mineralized nutrients which causes sufficient crop growth and facilitates higher yield over no residue (Shrivastav, 2014 and Dahal, 2014). Straw for controlling weeds in different crops have been suggested by Devasinghe et al. (2011). Residues prevents weed growth and supplies organic matter for heterotrophic $\mathrm{N}$ fixing microorganisms, which could be utilized by succeeding crops consequently results the higher yield (Mendoza and Samson, 1999; Patnaik, 1978).

\section{Conclusion}


Considering the rice grain yield and $\mathrm{BCR}$, it may be concluded that, unpuddled rice transplantation may be a good alternative to existing conventional practice. Farmers are likely to be benefited with the adoption of unpuddled system with the retention of crop residues in the field.

\section{References}

Bhuiyan, S. I., M. A. Sattar, and D. F. Tabbal. 1995. Wet seeded rice: water use efficiency and productivity and constraints to wider adoption. In Moody (ed) constraints, opportunities and innovations for wet seeded rice, Los Banos (Phillipines): IRRI. pp: 143-55.

Brammer, H. 1996. The geography of the soils of Bangladesh. University Press Limited, Dhaka, Bangladesh.

Devasinghe, D. A. U. D., K. P. Premarathne and U. R. Sangakkara. 2011. Weed management by rice straw mulching in direct seeded lowland rice (Oryza sativa L.). Tropical Agric. Res. 22 (3): 263 - 272.

Grace, P. R. 2003. Rice-wheat system and climatic change. Addressing resource conservation issues in rice-wheat systems of South Asia: A resource book. Rice-wheat consortium for the Indo-Gangetic Plains. International Maize and Wheat Improvement Center, New Delhi, pp. 63-67

Gupta, R. K., P. R. Hobbs, L. Harrington and J. K. Ladha. 2003. Rice-wheat system: problem analysis and strategic entry points, addressing resource conservation issues in rice-wheat systems of South Asia: A resource book, Rice-Wheat Consortium for the Indo-Gangetic Plains - International Maize and Wheat Improvement Centre, New Delhi, pp.16-23.

Haque, M. E., M. I. Hossain, M. A. Wohab, K. D. Sayre, R. W. Bell and J. Timsina. 2008. Agricultural mechanization in Bangladesh and conservation agriculture: The opportunities, priorities, practices and possibilities. Forth International Conference of Conservation Agriculture. February 2009, New Delhi, India.

Heatherly, L. G., C. D. Elmore and S. R. Spurlock, 1994. Effect of irrigation and weed control treatment on and net return from soybean (Glycine max L.). Weed Technol. 8: 69-76.

Hobbs, P. and M. Morris 1996. Meeting South Asia's future food requirement from rice-wheat cropping systems: Issues facing researchers in the post-green revolution era. NRG paper 96-01 Mexico, D.F., CIMMYT.

Islam, A. K. M. S., M. M. Hossain and M. A., Saleque. 2014. Effect of unpuddled transplanting on the growth and yield of dry season rice (Oryza sativa L.) in High Barind Tract. The Agriculturists. 12(2): 91-97.

Islam, A. K. M. S., M. M. Hossain, M. A. Saleque, M. A. Rahman, B. Karmakar and M. E. Haque. 2012. Effect of minimum tillage on soil properties, crop growth and yield of aman rice in drought prone northwest Bangladesh. Bangladesh Agron. J. 15(1): 43-51.

Kennedy, A. C. 1999. Soil microorganisms for weed management. J. Crop Prod. 2: 123-138.

Kumar, K. and K. M. Goh. 2000. Crop residues and management practices: effects on soil quality, soil nitrogen dynamics, crop yield and nitrogen recovery. Adv. Agron. 68: 198-279.

Mahajan, G., L. S. Brar and U. S. Walia. 2002. Phalaris minor response in wheat in relation to planting dates, tillage and herbicides. Indian J. Weed Sci. 34: 213-215.

Mendoza, T. C. and R. Samson. 1999. Strategies to avoid crop residue burning in the Philippine context. In: International Conference of "Frostbite and Sun Burns" Canadian International Initiatives Toward Mitigating Climate Change hosted by Internation Program (IP) of the Camadia Environmental Network (CEN) and the Salvadorn Center for Appropriate Technology (CESTA) held on 24 April-May 2. p.13. 
Hossain et al.

Miah, M. A. M., M. S. Islam and M. T. H. Miah. 2002. Socio-economic impacts of farm mechanization on the livelihoods of rural labourers in Bangladesh. J. Farm Econ. 12: 147-162.

Patnaik, S. 1978. Natural sources of nutrients in rice soils. In Soil and Rice. P. 501-20. IRRI, Los Banos, Laguna, Philippines.

Piggin, C. M., C. O. Gracia and J. D. Janiya. 2002. Establishment of irrigated rice under zero and conventional tillage system in the Philippines. In Proc. Int. workshop on herbicide resistance management and zero tillage in rice-wheat system. March 4-6, Hisar, India, 190-95.

Sayre, K. D. and P. Hoobs. 2003. Raised bed system of cultivation for irrigated production condition bed planting course, CIMMYT, Mexico.

Sharma, P. K., K. T. Ingram and D. Harnpichitvitaya. 1995. Subsoil compaction to improve water use efficiency and yields of rainfed lowland rice in coarse-textured soils. Soil and Tillage Res. 36: $33-44$.

Shrivastav, N. 2014. Weed dynamics and productivity of spring maize under different tillage and weed management methods. M.Sc. Ag. Thesis, Tribhuvan University, Department of Agronomy, IAAS, Rampur, Chitwan, Nepal.

Singh, A., R. Kumar and J. S. Kang. 2014. Tillage system, crop residues and nitrogen to improve the productivity of direct seeded rice and transplanted rice. Curr. Agri. Res. J. 2(1): 14-29. 